\title{
Targeted disruption of SHIP leads to hemopoietic perturbations, lung pathology, and a shortened life span
}

\author{
Cheryl D. Helgason, ${ }^{1}$ Jacqueline E. Damen, ${ }^{1}$ Patty Rosten, ${ }^{1}$ Rewa Grewal, ${ }^{1}$ Poul Sorensen, ${ }^{2}$ \\ Suzanne M. Chappel, ${ }^{1}$ Anita Borowski, ${ }^{3}$ Frank Jirik, ${ }^{3}$ Gerald Krystal, ${ }^{1}$ and R. Keith Humphries ${ }^{1,4,5}$ \\ ${ }^{1}$ Terry Fox Laboratory, British Columbia Cancer Agency, Vancouver, British Columbia V5Z 1L3, Canada; ${ }^{2}$ Department \\ of Pathology and Laboratory M edicine, University of British Columbia, Vancouver, British Columbia V6T 2B5, Canada; \\ ${ }^{3}$ Center for Molecular Medicine and Therapeutics, University of British Columbia, Vancouver, British Columbia V6T 1Z4, \\ Canada; ${ }^{4}$ Department of M edicine, University of British Columbia, Vancouver, British Columbia V6T 2B5, Canada
}

\begin{abstract}
SHIP is a 145-kD SH2-containing inositol-5-phosphatase widely expressed in hemopoietic cells. It was first identified as a tyrosine phosphoprotein associated with Shc in response to numerous cytokines. SHIP has been implicated in FCyRIIB receptor-mediated negative signaling in B cells and mast cells and is postulated to down-regulate cytokine signal transduction in myeloid cells. To define further its role in the proliferation and differentiation of hemopoietic progenitors, as well as its function in mature cells, we have generated embryonic stem cells and mice bearing a targeted disruption of both SH IP alleles. Here we show that although SHIP null mice are viable and fertile, they fail to thrive and survival is only $40 \%$ by 14 weeks of age. Mortality is associated with extensive consolidation of the lungs resulting from infiltration by myeloid cells. Increased numbers of granulocyte-macrophage progenitors are observed in both the bone marrow and spleen of SHIP-1- mice, perhaps as a consequence of hyper-responsiveness to stimulation by macrophage-colony stimulating factor, granulocyte-macrophage colony stimulating factor, interleukin-3, or Steel factor as observed in vitro. In contrast, numbers of bone marrow lymphoid and late eythroid progenitors (CFU-E) are reduced. Thus, homozygous disruption of SHIP establishes the crucial role of this molecule in modulating cytokine signaling within the hemopoietic system and provides a powerful model for further delineating its function.
\end{abstract}

[Key Words: SHIP; hemopoiesis; embryonic stem cells; knockout; signal transduction]

Received March 18, 1998; revised version accepted A pril 13, 1998.

SHIP (SH2-containing inositol-5-phosphatase) is a recently cloned 145-kD protein that is highly expressed in hemopoietic cells (Damen et al. 1996; Kavanaugh et al. 1996; Li oubin et al . 1996). It contains an amino-terminal src homology 2 (SH2) domain, a central 5'-phosphoinositol phosphatase domain, two phosphotyrosine binding (PTB) consensus sequences, and a proline-rich region at the carboxyl tail. SHIP becomes tyrosine phosphorylated following activation of the hemopoietic cell-surface receptors for numerous cytokines including erythropoietin (Epo), Steel factor (SF), interleukin-3 (IL-3) (Cutler et al. 1993; Damen et al. 1993), IL-2, granulocyte-macrophage colony-stimulating factor (GM-CSF), and macrophage colony stimulating factor (M-CSF) (Lioubin et al. 1994). Similarly, cross-linking of the B-cell antigen receptor (Saxton et al. 1994) or T-cell activation (Ravichandran et al. 1993) induce SHIP phosphorylation.

It has been postulated that SHIP may impact on many

${ }^{5}$ Corresponding author.

E-MAIL keith @teryfox.ubc.ca; FAX (604) 877-0712. signal transduction pathways in hemopoietic cells. For example, SHIP selectively hydrolyzes the 5'-phosphate from inositol 1,3,4,5-tetraphosphate and phosphatidylinositol 3,4,5-trisphosphate $\left(\mathrm{PIP}_{3}\right)$, the latter being a product of phosphatidylinositol 3'-kinase (PI-3-K) activity. PI-3-K activation in response to growth factor stimulation is implicated as a major step in mitogenic signaling (Kapeller and Cantley 1994). In addition, both phosphatidylinositol 3,4-bisphosphate and $\mathrm{PIP}_{3}$ may play a role in regulating the $\mathrm{PKB} / \mathrm{Akt}$ kinase (M arte and Downward 1997). Interestingly, the catalytic activity of SHIP is not altered following cytokine stimulation, suggesting that its subcellular localization may be an important regulatory factor (Damen et al. 1996). In this regard, phosphorylated SHIP has been shown to associate with Shc (Liu et al . 1997a), Grb2 (Osborne et al. 1996), and the tyrosine phosphatase SHP-2 (Liu et al. 1997b; Sattler et al. 1997), which may change its proximity to the membrane and/or various substrates. Furthermore, association with these molecules suggests that SHIP may function in coupling cytokine receptor activation to the Ras 
signaling pathway in hemopoietic cells (Scharenberg and Kinet 1996; Liu et al. 1997c; Tridandapani et al. 1997). Thus, SHIP may regulate the proliferation and differentiation of hemopoietic cells by modulating $\mathrm{PIP}_{3}$ levels and Ras activity following cytokine stimulation.

SHIP has been implicated in the negative signaling pathways that abrogate activation in cells of the immune system. Coligation of the low-affinity Fc receptor for immunoglobulin G (IgG) (FcyRIIB) with the B-cell receptor $(B C R)$ or the high-affinity mast cell IgE receptor (FCERI) blocks the influx of extracellular calcium with minimal effects on the release of calcium from intracellular stores. This perturbation of calcium signaling may mediate the negative signals on B-cell growth and mast-cell degranulation. Studies with both mast and B cells derived from mice deficient in SHP-1 (me/me) suggest that SHIP is the primary mediator of inhibitory Fc $\gamma$ RIIB signaling (Ono et al. 1996; N adler et al. 1997). It is unclear however whether SHIP is an inhibitor of cytokine signal transduction pathways regulating the proliferation and differentiation of other hemopoietic progenitors. Ectopic expression of SHIP in the FDC-P1 cell line significantly reduces $M-C S F-d e p e n d e n t$ growth (Lioubin et al. 1996) and increases apoptosis in the DA-ER murine hemopoietic cell line (Liu et al. 1997a). These observations suggest that SHIP may down-regulate signals required for survival and proliferation.

Targeted disruption using homologous recombination in embryonic stem (ES) cells was carried out to further define the role of SHIP in the proliferation and differentiation of hemopoietic progenitors, as well as its function in mature cells. The data presented suggest that SHIP plays an important role in down-regulating the mitogenic signals initiated through stimulation of numerous growth factor receptors. Absence of SHIP results in a myeloproliferative-like syndrome and consolidation of the lungs by infiltration of macrophages, with a consequent decrease in the survival of SHIP ${ }^{-1-}$ mice.

\section{Results}

\section{Targeted disruption of SHIP}

To examine the in vivo function of SHIP, targeted disruption of the murine SHIP gene was achieved using a strategy in which the entire 254-bp coding sequence of the first exon was replaced with the neomycin resistance gene in the antisense orientation using either of the two targeting vectors described in Figure $1 \mathrm{~A}$. Two lines of SHIP knockout mice, one generated with each targeting vector, were derived using standard techniques. Southern bl ot analysis of genomic DNA from both the targeted ES cells and representative $\mathrm{F}_{2}$ mice using a 2-kb KpnlHindlII genomic probe confirmed the expected targeting event (Fig. 1B). Western blot analysis of hemopoietic cells derived from the in vitro differentiation of SHIP wild type $(+/+)$, heterozygous $(t-)$, and null $(-t \rightarrow$ R 1 ES cells, as well as bone marrow cells derived from mice of each genotype, confirmed the absence of full-length or truncated protein products in the SHIP ${ }^{-1-}$ cells (Fig. 1C).
SHIP ${ }^{-1-}$ mice fail to thrive and have profound splenomegaly

Wild-type, heterozygous, and null $\mathrm{F}_{2}$ progeny were present at the expected Mendelian ratio of 1:2:1 $(n=360)$. Although both male and female SHIP ${ }^{-1-}$ mice were viable and fertile, they failed to thrive and exhibited a $17 \%$ reduction in body weight at 4-5 weeks of age with a further $5 \%$ decrease by $8-10$ weeks of age (Table 1 ). Splenomegaly was also a striking feature in $\mathrm{SHIP}^{-1-}$ mice of both age groups, with nucleated cell counts increased two- to threefold above $H+$ and $H$-littermate controls. Total spleen cellularity (red + white cells) and weights were increased five- to sevenfold in the 8-10week-old knockout animals (not shown). In contrast, the bone marrow of SHIP null mice became progressively hypocellular with age (Table 1). The cellularity of the thymus and Iymph nodes obtained from SHIP ${ }^{-1}$ mice in these two age groups was highly variable and therefore the differences compared with the $H+$ mice were not significant. In all cases the phenotype of the $H-$ mice more closely resembled that of the wild-type mice.

SHIP ${ }^{-1-}$ mice have a shortened life span associated with massive myeloid cell infiltration of the lungs

Homozygous knockout mice became moribund as early as 4 weeks of age and over $50 \%$ died by 10 weeks of age (Fig. 2). Gross anatomical examination of SHIP $\mathrm{P}^{-1-}$ mice at 8-10 weeks of age revealed, in addition to the pronounced splenomegaly, a uniform enlargement and patchy whitish discoloration of the pleural surfaces of the lungs compared to littermate controls (Fig. 3A). Histologic examination revealed a massive infiltration of the air spaces with distended lipid-Iaden macrophages, many of which were multinucleated (Fig. 3B,C). The histiocytic origin of these cells was corroborated by strong chloracetate esterase staining (Fig. 3D). The infiltrates were located primarily in alveolar spaces in the pattern of lipoid pneumonia. In addition, collections of neutrophils were distributed throughout the consolidated areas, and in some sections neutrophils were present in bronchiolar lumens. Although the degree of lung involvement was extensive and became progressively pronounced with age, the infiltrates were somewhat patchy in that areas of normal lung could be found adjacent to abnormal areas (Fig. 3B). Stains for bacteria and fungi were negative, and serological testing showed no evidence of viral pathogens or mycoplasma, ruling out obvious infectious causes. Similar lung histopathology was observed in the second line of $\mathrm{SHIP}^{-1-}$ mice generated and housed in a separate pathogen-free animal facility (not shown).

Numerous hemopoietic abnormalities are observed in SHIP ${ }^{-1-}$ mice

Because SHIP is believed to play an important role in the hemopoietic system, various hematological parameters of these mice were examined. N o significant abnormali- 
Figure 1. Targeted disruption of the murine SHIP gene. (A) Partial restriction map of the wild-type 129 SHIP gene (Wild type), the tkcontaining targeting vector that replaces the coding sequence of the first exon with the $\mathrm{Neo}$-resistance gene in the antisense orientation (Vector), and the organization of the targeted 129 allele (Targeted). (Dashed lines) Area of homology between the vector and the endogenous gene. The $2.0-\mathrm{kb}$ genomic probe used for screening is indicated along with expected sizes of the wild-type and targeted Kpnl fragments. (B) Genomic Southern bl ot analysis using a 2-kb Kpnl-HindllI genomic probe. The nontargeted SHIP allele is visualized as a 4.6-kb band in the wild-type ES cells and a 2.9-kb C57BI/ 6 band in the mice (because of a polymorphism at this locus), whereas the SHIP $\mathrm{P}^{-1-}$ cells and mice contain only the targeted 5.8-kb band. (C) Western blot analysis. R1 SHIP wild-type $(+/+)$, heterozygous $(+t)$, and null $(-t \rightarrow$ ES cells were differentiated in vitro as described previously (Helgason et al. 1996). Hemopoietic cells were derived from suspension cultures of day 10 embryoid bodies, and total cell lysates were probed with an antibody against the carboxy-terminal region spanning the two N PxY sequences of SHIP. The predominant 145- and 135-kD forms are indicated at left. Total cell lysates were also prepared from freshly isolated bone marrow of representative $F_{2}$ mice and blots were probed with an antibody against the amino terminal $\mathrm{SH} 2$ domain. The predominant 110-kD protein is indicated at right.
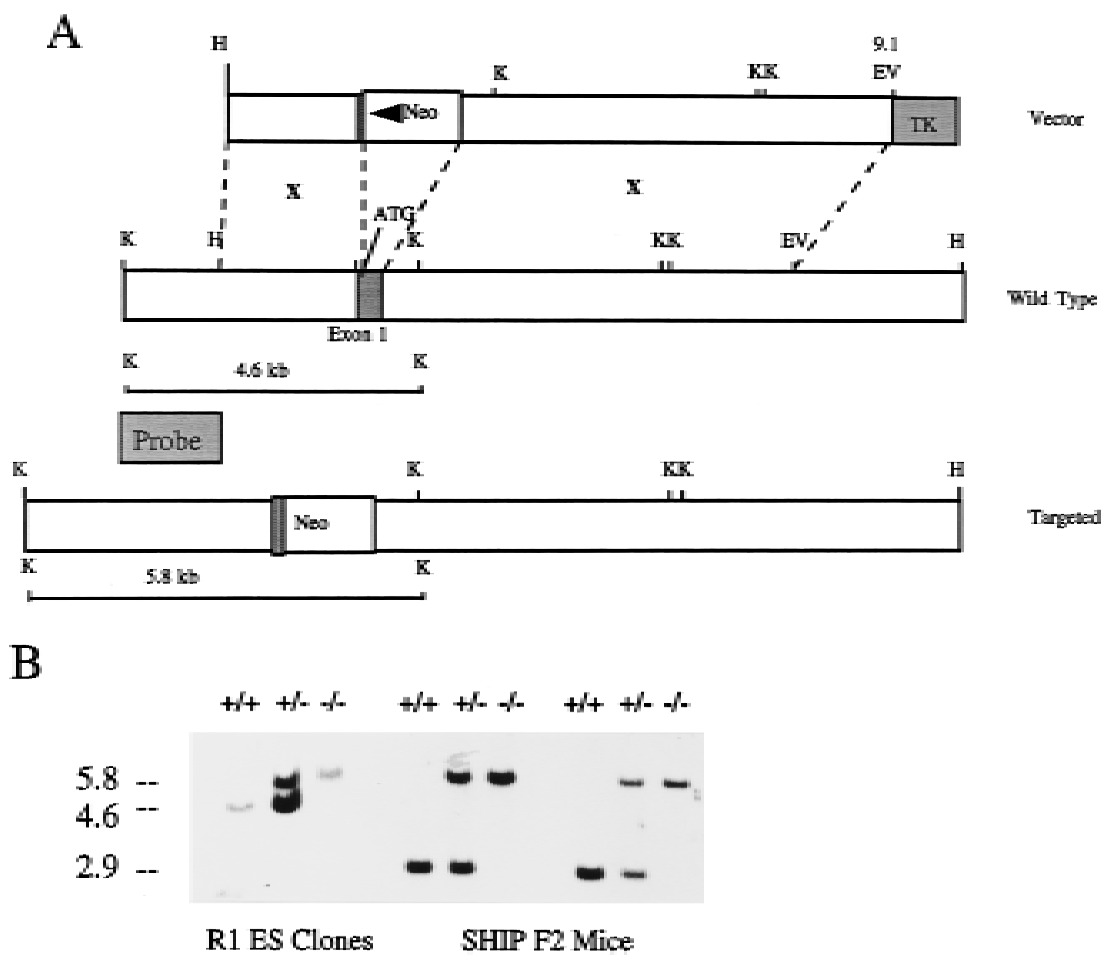

C

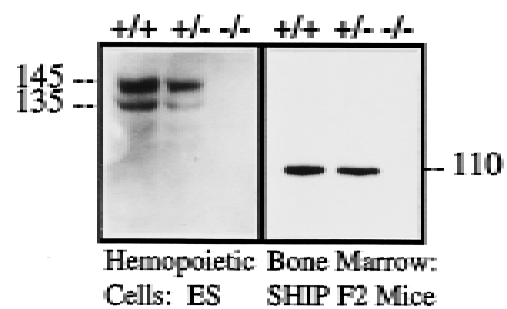

reveal ed a substantial increase in the percentage of circulating monocytes and mature neutrophils with a concomitant decrease in the percentage of circulating lym- ties were observed in hematocrits, peripheral blood white cell counts, or peripheral blood red cell counts. However, differential counts of peripheral blood smears

Table 1. Characterization of SHIP $F_{2}$ mice

\begin{tabular}{|c|c|c|c|c|}
\hline Parameter & $\begin{array}{c}\text { Age } \\
\text { (weeks) }\end{array}$ & $H t^{a}$ & $H-a$ & $--^{a}$ \\
\hline Body weight (grams) & $\begin{array}{l}4-5 \\
8-10\end{array}$ & $\begin{array}{l}20.5 \pm 1.1 \\
26.9 \pm 1.6\end{array}$ & $\begin{array}{l}19.8 \pm 1.3 \\
25.3 \pm 1.5\end{array}$ & $\begin{array}{l}17.0 \pm 0.6 * \\
20.9 \pm 1.0^{* *}\end{array}$ \\
\hline Cellularity ${ }^{\mathrm{b}}$ & & & & \\
\hline spleen $\left(\times 10^{8}\right)$ & $\begin{array}{l}4-5 \\
8-10\end{array}$ & $\begin{array}{l}1.5 \pm 0.1 \\
2.0 \pm 0.2\end{array}$ & $\begin{array}{l}2.5 \pm 0.3 \\
2.0 \pm 0.3\end{array}$ & $\begin{array}{l}3.3 \pm 0.4^{* *} \\
6.0 \pm 0.4^{* *}\end{array}$ \\
\hline BM (no./femur $\times 10^{7}$ ) & $\begin{array}{l}4-5 \\
8-10\end{array}$ & $\begin{array}{l}1.5 \pm 0.1 \\
1.5 \pm 0.2\end{array}$ & $\begin{array}{l}1.4 \pm 0.2 \\
1.3 \pm 0.2\end{array}$ & $\begin{array}{l}1.2 \pm 0.2 \\
1.0 \pm 0.1 *\end{array}$ \\
\hline thymus $\left(\times 10^{8}\right)$ & $\begin{array}{l}4-5 \\
8-10\end{array}$ & $\begin{array}{l}2.1 \pm 0.5 \\
1.3 \pm 0.1\end{array}$ & $\begin{array}{l}1.9 \pm 0.3 \\
1.7 \pm 0.3\end{array}$ & $\begin{array}{l}1.9 \pm 0.1 \\
1.9 \pm 0.2\end{array}$ \\
\hline Iymph nodes ${ }^{c}\left(\times 10^{7}\right)$ & $\begin{array}{l}4-5 \\
8-10\end{array}$ & $\begin{array}{l}1.4 \pm 0.5 \\
4.7 \pm 1.2\end{array}$ & $\begin{array}{l}2.0 \pm 0.6 \\
\text { N.D. }\end{array}$ & $\begin{array}{l}4.8 \pm 2.7 \\
5.7 \pm 0.5\end{array}$ \\
\hline
\end{tabular}

a Values represent the mean \pm S.E.M. for at least three animals per determination. (N.D.) N ot done. Statistical significance compared with the $H+$ populations was determined using the Student's t-test where $P \leqslant 0.05(*)$ and $P \leqslant 0.005(* *)$.

${ }^{b} \mathrm{~N}$ ucleated cell counts determined using acetic acid for cell dilutions.

Includes mesenteric, 2 popliteal, and 4 axial nodes. 


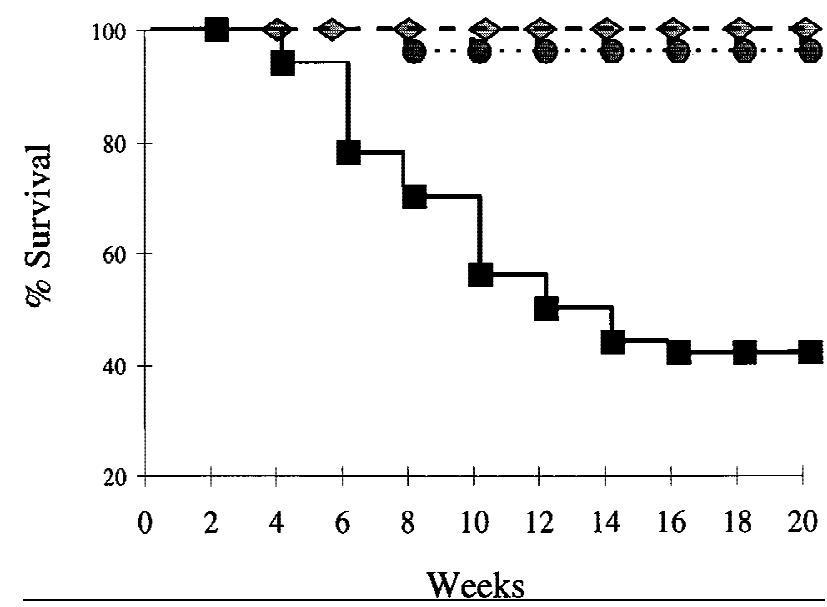

Figure 2. Decreased survival of $\mathrm{SHIP}^{-1-}$ mice. $\mathrm{F}_{2}$ littermates [14 $+/+$ (diamonds) , $22+/-$ (circles), and $14-1-$ (squares)] were followed over time and the percentage of surviving mice is indicated as a function of time.

phocytes (Table 2). Cytospins of bone marrow from SHIP ${ }^{-1-}$ mice showed a similar increase in mature neutrophils, with a reduction in Iymphoid and late erythroid cells (not shown).

Flow cytometric analysis of selected hemopoietic organs was carried out to further characterize the nature of the hemopoietic perturbations in the SHIP-1mice. The percentage of cells staining positive for both M ac- 1 and Gr-1 (M ac- $\left.1^{+} \mathrm{Gr}-1^{+}\right)$, representing monocytes and granulocyte progenitors, was significantly elevated [1.69 \pm 0.16 -fold ( $P=0.005 ; n=5$ ) above + + littermates] in the marrow of SHIP ${ }^{-1-}$ mice (Fig. 4A, upper panel). In contrast, significant reductions in the percentage of bone marrow cells expressing the B220 antigen were noted (Fig. 4A, middle panel). In 8-10-week-old SHIP-1mice the percentage of $\mathrm{B} 22 \mathrm{O}^{\text {bright }}$ cells was reduced to $\sim 20 \%$ of wild-type levels $(5.03 \pm 0.58 \%$ for wild type
VS. $0.95 \pm 0.12 \%$ for $\mathrm{SHIP}^{-1} ; \mathrm{P}=0.005 ; \mathrm{n}=3$ ). Similarly, the percentage of bone marrow Ter119-positive erythroid cells was decreased to $70.0 \pm 5.7 \%$ of wild-type levels in the 4-week-old animals (Fig. 4A, lower panel). The marrow erythroid component was reduced to $30 \%$ of normal $\left(31.29 \pm 4.94 \%\right.$ Ter $119^{+}$for $H+$ compared to $10.16 \pm 1.92 \%$ for $\mathrm{SHIP}^{-1-} ; \mathrm{n}=3$; $\mathrm{P}=0.03$ ) by $8-10$ weeks of age. Because the bone marrow cellularity (Table 1 ), as well as the percentages of $\mathrm{B}^{2} 20^{+}$and $\mathrm{Ter} 119^{+}$cells, are reduced in these older $\mathrm{SHIP}^{-1-}$ mice, total numbers of B-lymphoid and late erythroid cells are significantly reduced in the marrow compartment. In contrast, when the increased percentage of $\mathrm{Mac}-1^{+} \mathrm{Gr}-1^{+}$cells is examined in the context of the decreased marrow cellularity, absol ute numbers of these cells are not significantly different in the SHIP ${ }^{-1-}$ mice compared to their ++ littermates. Results of phenotypic analysis of bone marrow cells derived from $+/-$ mice were similar to those of the wild-type cells (not show).

Representative FACS profiles from the analysis of splenic cells isolated from 4-5-week-old littermates are presented in Figure 4B. At this age there are no significant differences in the percentages of cells that are $\mathrm{Mac}-1^{+} \mathrm{Gr}-1^{+}, \mathrm{B}_{22} 20^{+}$, or Ter $119^{+}$in the SHIP null mice $(n=5)$. However, because spleen cellularity of SHIP-1mice is increased twofold relative to $+/+$ mice (Table 1 ), absolute numbers of cells expressing each of these markers are el evated $\sim$ twofold. In spleens from 8-10-week-ol d $\mathrm{SHIP}^{-1-}$ mice there are almost 4.5 times as many Mac- $1^{+} \mathrm{Gr}-1^{+}$cells $(6.0 \pm 0.2 \%$ in $H+$ compared with $26.2 \pm 5.3 \%$ for $\left.\mathrm{SHIP}^{-1-} ; \mathrm{n}=3 ; \mathrm{P}=0.03\right)$. This translates into a 12-fold increase in absolute numbers of granulocyte progenitors and monocytes when the increased spleen cellularity is considered.

Normal proportions of CD4 and CD 8 single-positive, double-positive, and double-negative thymocytes were seen in SHIP-1- mice at both 4-5 weeks of age (Fig. 4C) and 8-10 weeks of age (not shown). FACS analysis of peripheral blood cells reveal ed an increased percentage of

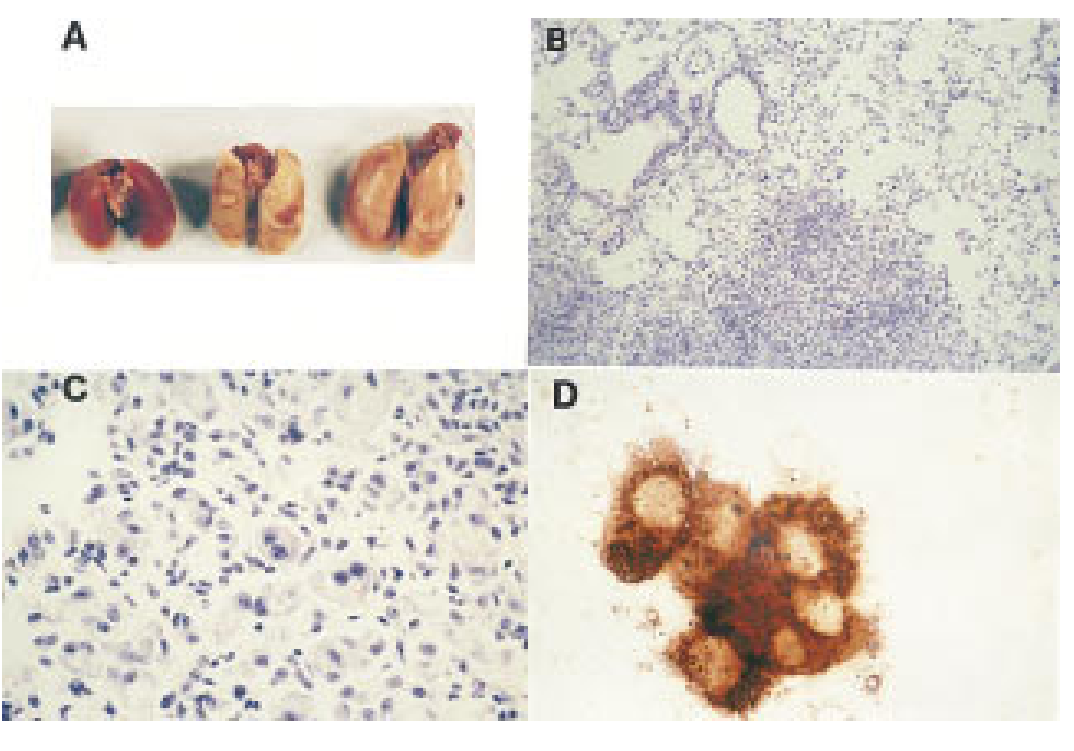

Figure 3. Lung pathology observed in SHIP ${ }^{-1-}$ mice. (A) Representative gross appearance of lungs from a 4-week-old wild-type (left) and two 4-week-old SHIP ${ }^{-1-}$ mice (right) showing diffuse enlargement and patchy pleural discoloration of the lungs from the knockout mice. (B) Low power micrograph of $\mathrm{H} \& \mathrm{E}$ stained sections from a representative 8-weekold $\mathrm{SHIP}^{-1-}$ mouse showing patchy cellular infiltrates in alveolar airspaces adjacent to relatively normal appearing lung. (C) High power photomicrograph of $H \& E$ stained sections from an 8-week-old knockout mouse demonstrating alveolar infiltration by lipid-laden macrophages, including multinucleated forms, as well as collections of neutrophils mixed with the macrophages. (D). Chloracetate esterase stains for macrophages showing strong reactivity of alveolar cell infiltrates of the SHIP-1-lung. 


\section{Helgeson et al.}

Table 2. Hematological parameters of SHIP $F_{2}$ mice

\begin{tabular}{|c|c|c|c|c|}
\hline Parameter & $\begin{array}{c}\text { Age } \\
\text { (weeks) }\end{array}$ & $H t^{a}$ & $H_{-a}^{a}$ & $-1-^{a}$ \\
\hline \multirow[t]{2}{*}{ Hematocrit (\%) } & $4-5$ & $47.5 \pm 1.3$ & $49.0 \pm 1.2$ & $48.9 \pm 2.8$ \\
\hline & $8-10$ & $50.7 \pm 1.0$ & $47.2 \pm 2.6$ & $42.4 \pm 5.7$ \\
\hline \multirow{2}{*}{ WBC $\left(\times 10^{7} / \mathrm{ml}\right)$} & $4-5$ & $1.1 \pm 0.0$ & $1.1 \pm 0.1$ & $1.3 \pm 0.3$ \\
\hline & $8-10$ & $1.0 \pm 0.1$ & $0.9 \pm 0.1$ & $1.0 \pm 0.1$ \\
\hline \multirow[t]{2}{*}{$\mathrm{RBC}\left(\times 10^{9} / \mathrm{ml}\right)$} & $4-5$ & $9.9 \pm 0.8$ & $10.4 \pm 0.3$ & $10.9 \pm 1.0$ \\
\hline & $8-10$ & $10.0 \pm 0.3$ & $10.1 \pm 0.3$ & $8.4 \pm 0.7$ \\
\hline \multicolumn{5}{|l|}{ Peripheral blood } \\
\hline \multirow[t]{8}{*}{ differential counts $(\%)^{a}$} & 4-5 L & $68.8 \pm 1.8$ & $62.3 \pm 2.4$ & $45.3 \pm 4.5^{* *}$ \\
\hline & $\mathrm{M}$ & $15.5 \pm 0.8$ & $13.3 \pm 0.4$ & $23.3 \pm 3.0^{*}$ \\
\hline & $\mathrm{N}$ & $14.8 \pm 1.9$ & $19.0 \pm 0.7$ & $28.0 \pm 2.1^{* *}$ \\
\hline & $E$ & 0 & $5.5 \pm 2.4$ & $3.3 \pm 0.4$ \\
\hline & $8-10 \mathrm{~L}$ & $73.3 \pm 2.6$ & $67.3 \pm 5.6$ & $39.2 \pm 3.2^{* *}$ \\
\hline & M & $10.0 \pm 1.4$ & $10.0 \pm 3.0$ & $25.0 \pm 4.2^{*}$ \\
\hline & $\mathrm{N}$ & $13.3 \pm 1.1$ & $23.3 \pm 3.4^{*}$ & $35.5 \pm 7.3^{*}$ \\
\hline & $E$ & $1.3 \pm 0.9$ & $0.8 \pm 0.7$ & $0.5 \pm 0.3$ \\
\hline
\end{tabular}

aValues represent the mean \pm S.E.M. for at least three animals per determination. Statistical significance compared with the $H+$ populations was determined using the Student's t-test where $\mathrm{P} \leqslant 0.05\left(^{*}\right)$ and $\mathrm{P} \leqslant 0.005\left(^{* *}\right)$.

aWright-Giemsa-stained smears of peripheral blood were scored microscopically based on morphol ogy. (L) lymphocyte; (M ) monocyte; (N) neutrophil; (E) eosinophil and others.

$\mathrm{Mac}-1^{+} \mathrm{Gr}-1^{+}$cells and a decreased percentage of cells expressing the B220 antigen (not shown). Thus, the FACS data are consistent with the changes observed in the counts of peripheral blood smears (Table 2).

SHIP $\mathrm{P}^{-1-}$ mice have decreased lymphoid and increased myeloid progenitor numbers

In order to determine if these perturbations in the hemopoietic organs and peripheral blood arise at the progenitor level, bone marrow cells from $\mathrm{SHIP}^{+/+}, \mathrm{SHIP}^{+1-}$, and SHIP $\mathrm{P}^{-1-}$ mice were plated in methylcellulose-based media and various assays performed. Absolute numbers of clonogenic progenitors observed with $H$-cells were similar to wild-type levels (data not shown). N umbers of pre-B lymphoid (Fig. 5A) colony-forming cells were reduced to $39 \%$ of normal in mice 4-5 weeks of age, whereas numbers of day 2 col ony-forming unit-erythroid (CFU-E) (Fig. 5B) progenitors were reduced to $47 \%$ of the levels observed in $+/+$ littermates. In both cases the re duction in progenitor numbers was more pronounced in animals 8-10 weeks of age. N either day 3 burst forming unit (BFU)-erythroid nor day 10 BFU-E progenitor numbers were significantly reduced (results not shown), suggesting a block in the late stages of erythroid maturation. Although slight increases were observed in the number of granulocyte-macrophage colony forming cells (CFC) in $\mathrm{SHIP}^{-1-}$ bone marrow (Fig. 5C), dramatic el evations were seen in the spleen (Fig. 5D). For example, CFC numbers were el evated almost 70-fold in the spleens of SHIP-1- mice 8-10 weeks of age. We observed similar increases in numbers of CFC-GM , and decreases in CFU $\mathrm{E}$, using the $\mathrm{SHIP}^{-1-}$ ES cells in an in vitro differentiation system (not shown) suggesting that these variations in differentiation potential are intrinsic to the progenitor cells.
Hemopoietic progenitors lacking SHIP are hyper-responsive to multiple cytokines

The generation and maturation of CFC can be achieved both in vitro and in vivo using a number of different growth factors. We therefore examined the colony-forming ability of SHIP ${ }^{-1-}$ bone marrow cells in methylcellul ose-based media containing various concentrations of cytokines that play a role in myeloid development. Under these conditions, SHIP ${ }^{-1-}$ bone marrow progenitors exhibited an enhanced sensitivity to all growth factors examined (Fig. 6). Both GM-CSF (Fig. 6A) and IL-3 (Fig. $6 \mathrm{~B}$ ) yielded $50 \%$ maximal colony formation at a 10 -fold lower concentration using SHIP-1- cells compared to those of $H+$ and $+/-$ littermates. These observations were confirmed using bone marrow derived from a second, independently derived line of SHIP null mice (not shown). In addition, SHIP $-1-$ bone marrow cells were some two- to threefold more sensitive to SF (Fig. 6C) and M-CSF (Fig. 6D).

In an attempt to determine if the absence of SHIP influenced colony size, suspension cultures were established with $\mathrm{SHIP}^{+/+}$or SHIP ${ }^{-1-}$ bone marrow cells in the presence of $0.01 \mathrm{ng} / \mathrm{ml} \mathrm{GM-CSF}$ or $1.0 \mathrm{ng} / \mathrm{ml} \mathrm{IL}-3$ under conditions similar to those used to assess colony formation. SHIP ${ }^{-1-}$ cultures yiel ded more cells in the presence of either GM-CSF or IL-3 than littermate control cultures. Moreover, if the cell yields from these suspension cultures were divided by the number of colonies generated in methylcellulose, it appears that the GM-CSFstimulated $\mathrm{SHIP}^{-1-}$ colonies were approximately double the size of those generated by the wild-type cells. In contrast, no difference in colony size was observed in the presence of IL-3.

Growth-factor-independent colony formation is one property of certain transformed cell populations. In order 


\section{A Bone Marrow}

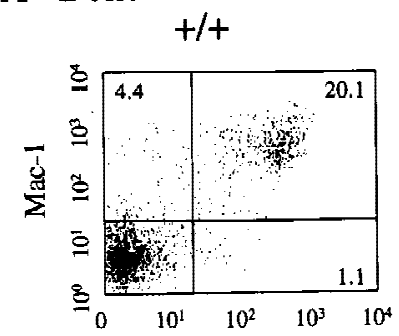

Gr-1
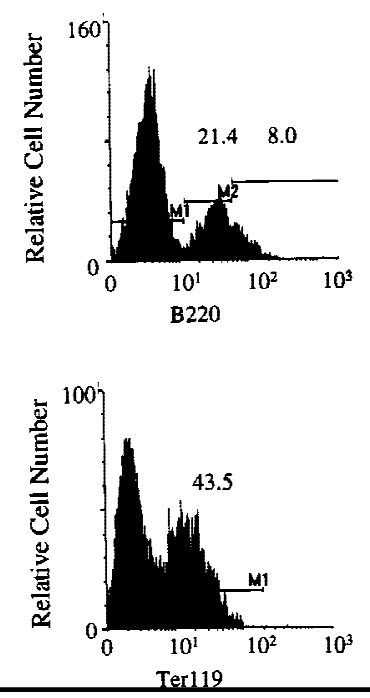

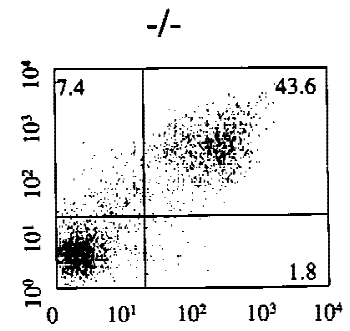

B Spleen
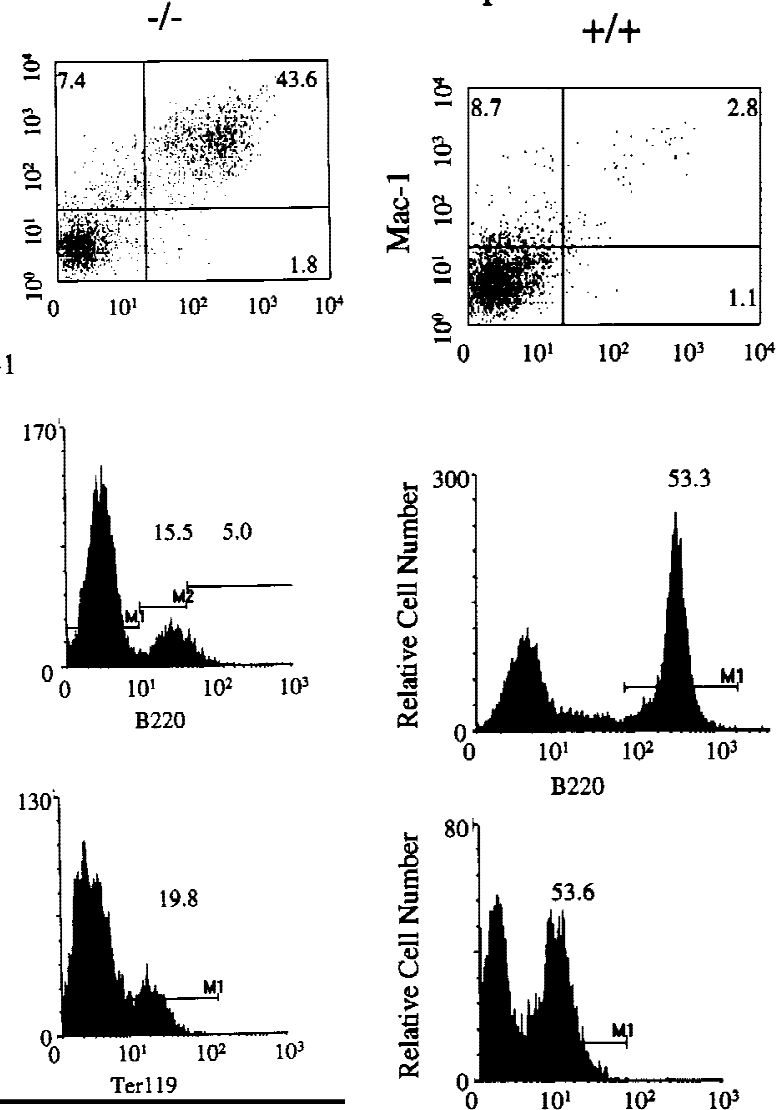
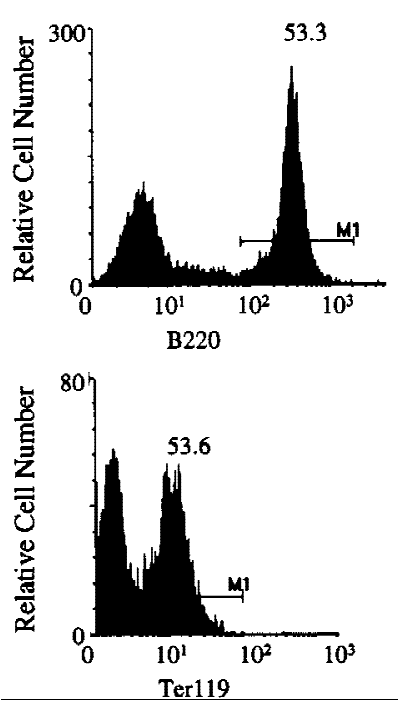

$-1-$

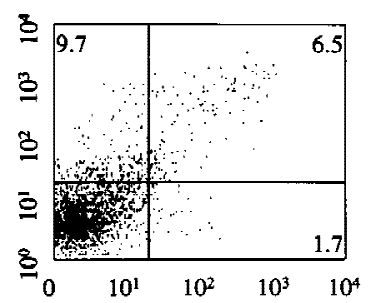

Gr-1
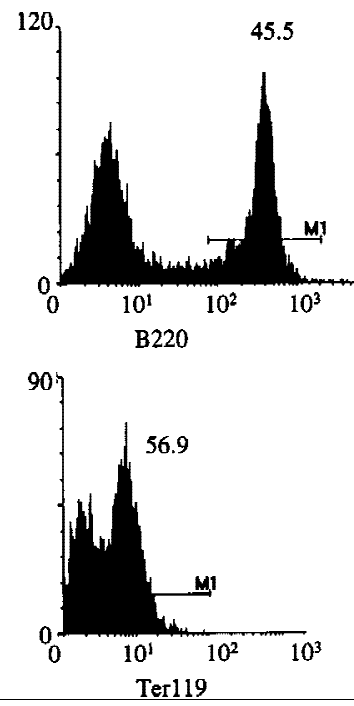

C Thymus

Figure 4. Representative FACS profiles of 4-5week-old SHIP $F_{2}$ mice. Five mice of each genotype were analyzed and the average percentages of positive cells determined. A FACS profile representative of each of these values is presented for bone marrow (A), spleen (B), and thymus (C) of SHIP wild-type $(+t)$ or null $(-t \rightarrow$ mice. N umbers represent the percent of viable $\left(\mathrm{PI}^{-}\right)$, positively stained cells within each marked region.
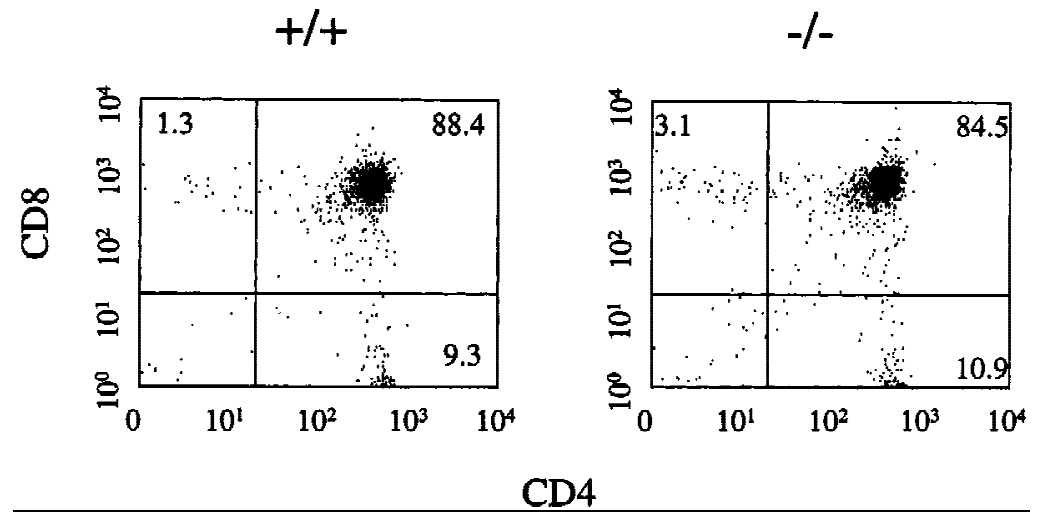

to evaluate the possibility that $\mathrm{SHIP}^{-1}$ progenitors possessed such potential, cells from all three genotypes of mice were plated in methylcellulose-based media containing $15 \%$ serum, but no growth factors. No colonies greater than 20 cells were observed in cultures from the wild-type, heterozygous, or SHIP null mice. However, $51.0 \pm 3.9 \%$ of the $\mathrm{SHIP}^{-1-}$ CFC detectable in cytokinecontaining media were capable of giving rise to small clusters ranging in size from 5-20 cel Is. N o such clusters were observed using cells from $+1+$ or $+1-$ mice, suggest- ing that SHIP ${ }^{-1-}$ progenitors exhibit enhanced survival, but only minimal proliferation, in the absence of exogenous growth factors.

\section{Discussion}

Tyrosine phosphorylation of SHIP is an early response to stimulation of many hemopoietic cell-surface receptors (Cutler et al. 1993; Damen et al. 1993; Lioubin et al. 1994). SHIP has been demonstrated to play a major role 
Figure 5. Altered myelopoiesis, erythropoiesis, and Iymphopoiesis in $\mathrm{SHIP}^{-1-}$ mice. In vitro hematopoietic colony formation was examined in methylcellulose colony assays using cells from wild-type (open bars) or null (solid bars) SHIP $F_{2}$ littermates at 4-5 weeks and 8-10 weeks of age. (A) Numbers of pre-B progenitors per femur detected in methylcellulose containing $10 \mathrm{ng} / \mathrm{ml} \mathrm{IL-7.} \mathrm{(B)} \mathrm{N} \mathrm{umbers} \mathrm{of} \mathrm{day}$ 2 CFU-E per femur detected in methylcelIulose supplemented with $50 \mathrm{ng} / \mathrm{ml} \mathrm{SF}$ and $3 \mathrm{U} / \mathrm{ml}$ Epo. Granulocyte-macrophage CFC per femur (C) or per spleen (D) were detected in methylcellulose containing 10 $\mathrm{ng} / \mathrm{ml} \mathrm{IL-3,} 10 \mathrm{ng} / \mathrm{ml} \mathrm{IL-6,} 50 \mathrm{ng} / \mathrm{ml} \mathrm{SF}$, and $3 \mathrm{U} / \mathrm{ml}$ Epo. In all cases, values represent the mean \pm S.E.M. of 3 or more duplicate determinations. Statistical significance compared to $+/+$ littermates was determined using the Student's t-test. $\mathrm{P} \leqslant 0.05(*) ; \mathrm{P} \leqslant 0.01(* *)$.
A
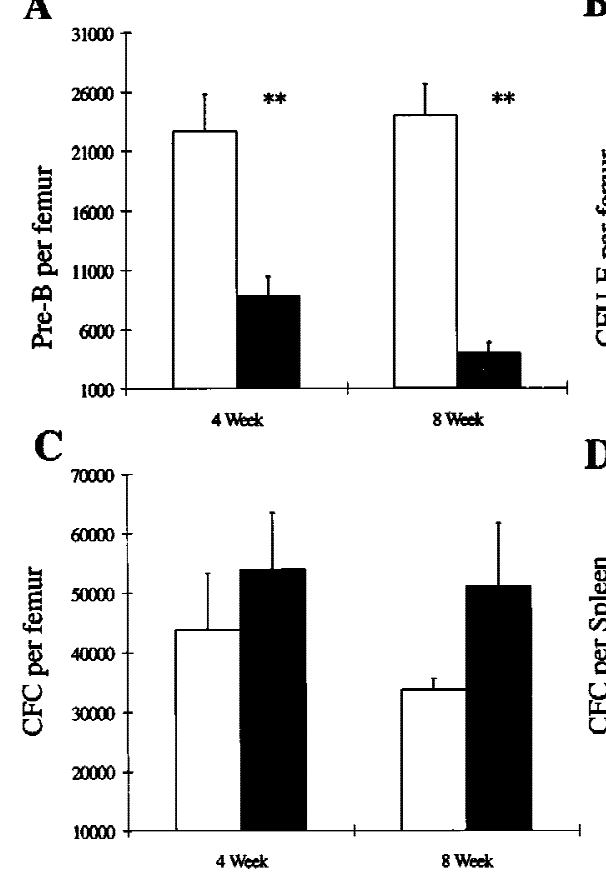

B

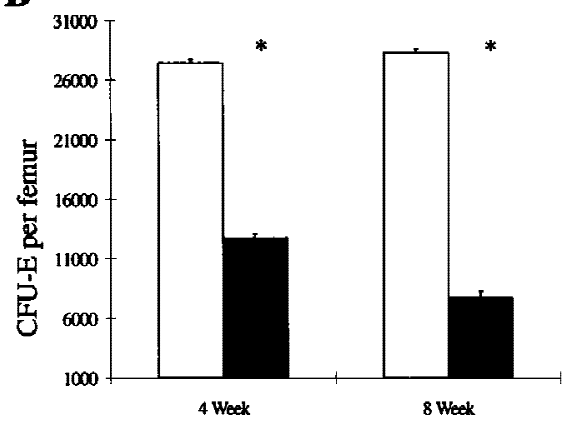

D

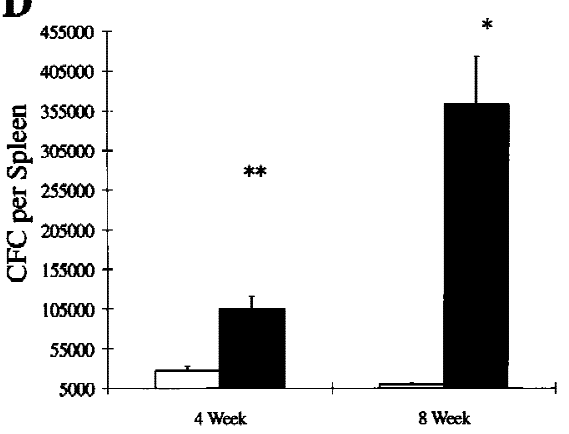

in FcyRIIB inhibitory signaling in both B cells (Ono et al . 1997) and mast cells (Ono et al. 1996). Thus, it has been postulated that SHIP may play a central role in negatively regulating the responses of both primitive and mature hemopoietic cells to external stimuli. We now demonstrate that the absence of SHIP in vivo results in a marked pathology exemplified by a shortened lifespan, pronounced splenomegaly, and massive myel oid cell accumulations in the lungs.

One of the most striking features of SHIP $\mathrm{P}^{-1-}$ mice was the decreased life span, with death observed as early as 4 weeks of age and only $40 \%$ of the animals surviving 14 weeks. We observed no major abnormalities in hematoxylin and eosin (H\&E) stained sections of the brain, liver, or kidney (results not shown). In addition, peripheral blood abnormal ities such as anemia, increased numbers of blast cells, or grossly elevated white cell counts were not seen. Thus, the most likely explanation for the early death of SHIP ${ }^{-1}$ - mice would appear to be gross impairment of lung function caused by myeloid cell infiltration. Interestingly, some mice have now survived as long as six months, al though they do exhibit decreases in body weight and a "scruffy" appearance. The variability in life span is most likely caused by the mixed genetic background inherent in the $F_{2}$ populations examined in this study.

Phenotypically, SHIP-1- mice bear some resemblance to normal mice transplanted with bone marrow cells engineered for retroviral-mediated overexpression of GMCSF. Splenomegaly, reductions in bone marrow cellularity, and patchy consolidation of the lungs, as well as decreased numbers of bone marrow erythroblasts and lymphocytes, were observed in these transplanted mice
(Johnson et al. 1989). SHIP-1- mice also exhibit marked increases in the numbers of granulocyte-macrophage progenitors in the bone marrow, and especially the spleen. These increases are associated with an enhanced sensitivity of SHIP ${ }^{-1-}$ granulocyte-macrophage progenitors to multiple cytokines including IL-3, GM-CSF, MCSF, and SF. In this regard, we have also observed an enhanced degranulation of $\mathrm{SHIP}^{-1}$ - bonemarrow-derived mast cells in response to IgE, suggesting that SHIP plays a major role in setting the threshold for cellular responses to external stimuli (M. Huber, C.D. Hel gason, J.E. Damen, L. Liu, R.K. Humphries, and G. Krystal, in prep.). Because the lungs are a major site of GM-CSF production (Tazi et al. 1993) and SHIP ${ }^{-1-}$ CFC exhibits a 10-fold increase in sensitivity to this cytokine, this may be sufficient to account for the abnormal accumulations of myeloid cells in the lung.

SHP-1, a protein-tyrosine phosphatase expressed primarily in hemopoietic cells (Yi et al. 1992), has been implicated as a negative regulator of signal transduction (Shultz et al. 1997). Mice homozygous for the mutated motheaten $\left(\mathrm{Hcph}^{\mathrm{me}}\right)$ or viable motheaten $\left(\mathrm{Hcph}^{\mathrm{me}} \mathrm{v}\right)$ alleles exhibit enhanced proliferation of monocyte/macrophage progenitors, splenomegaly, and a fatal hemorrhagic pneumonitis associated with accumulations of macrophages, granulocytes, and lymphocytes in the lungs (Tsui and Tsui 1994). A bsence of functional SHP-1 increases the proliferative response of macrophages from these mice to GM-CSF (Jiao et al. 1997), leading to the suggestion that deregulated prol iferation of myel oid cells may account for the phenotype of these mice.

The similarities between the phenotypes of $\mathrm{SHIP}^{-1-}$ and viable motheaten mice raise an important question 
A

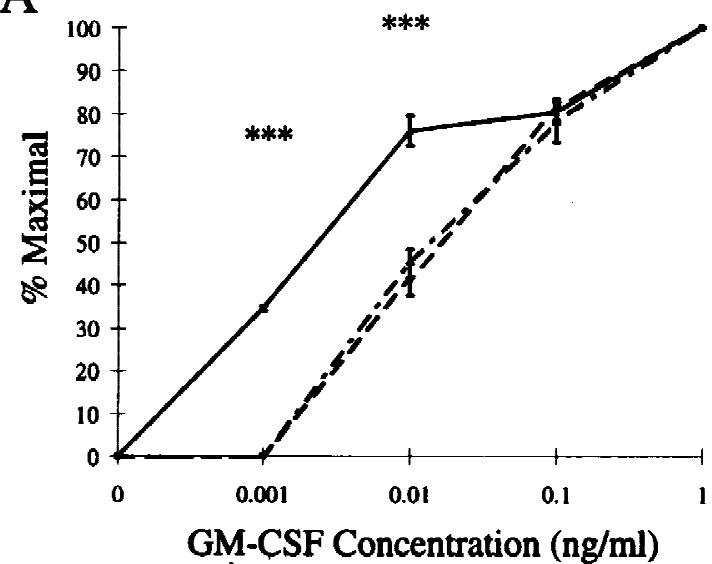

C

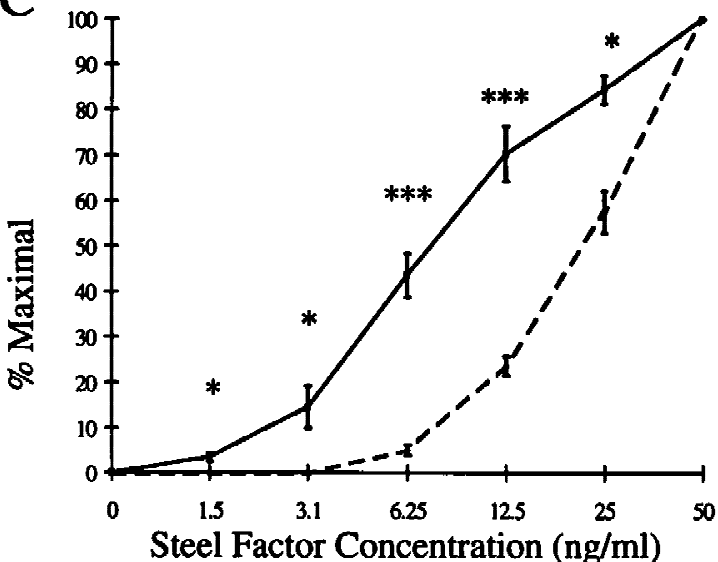

B

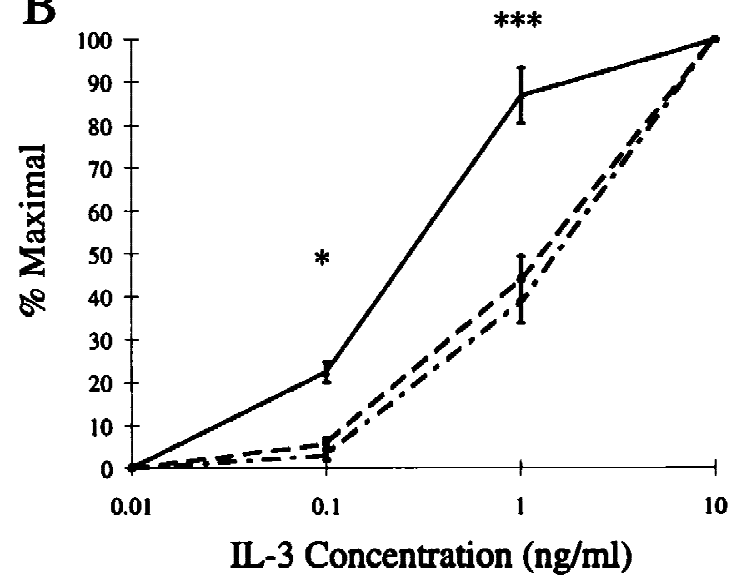

D

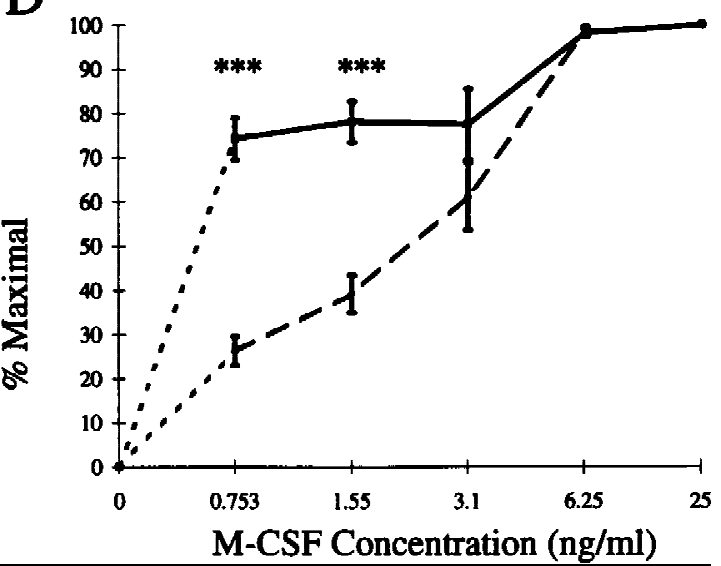

Figure 6. Altered growth factor responsiveness of SHIP ${ }^{-1-}$ CFC. Bone marrow derived from wild type (- -), heterozygous (- . -), or null (-) littermates was plated in methylcellulose containing the indicated concentrations of (A) GM-CSF, (B) IL-3, (C) Steel factor, or (D) $\mathrm{M}-\mathrm{CSF}$. Colonies of $>20$ cells were scored on day 10 of culture and the numbers of colonies present at each cytokine concentration were calculated as the percent of the number formed in the highest concentration of the cytokine indicated. Values represent the mean \pm S.E.M. for dupl icate determinations using at least three mice per group. Statistical significance compared to $+/+$ littermates was determined using the Student's t-test. $\mathrm{P} \leqslant 0.05(*) ; \mathrm{P} \leqslant 0.008(* * *)$.

regarding the relative importance of SHIP and SHP-1 in negatively regulating cytokine signaling. That is, do these molecules function independently, within the same pathway, or in an overlapping manner? Studies using homologous recombination in the chicken DT-40 cell line suggest that SHP-1 and SHIP function independently in response to signaling through different receptors (Ono et al. 1997). For example, signals initiated by the killer cell inhibitory receptor are mediated by SHP-1, but not SHIP. Conversely, the proapoptotic signals initiated by Fc $\gamma$ RIIB signaling are attenuated by SHIP but not SHP-1, suggesting that SHIP ${ }^{-1-}$ mice should exhibit B-Iymphoid perturbations. In fact, we observe decreased percentages of $\mathrm{B}_{2} 2 \mathrm{O}^{+}$cells in the bone marrow and spleen of SHIP $\mathrm{P}^{-1-}$ mice and pre-B colony-forming cell numbers are significantly reduced. Further phenotypic and functional analyses of the B-lymphoid populations are currently in progress to evaluate the consequences of loss of SHIP-mediated negative signaling.

Several signal transduction pathways may be involved in the enhanced growth factor sensitivity of the $\mathrm{SHIP}^{-1-}$ progenitors. One possible mechanism involves hyperactivation of the Ras pathway. SHIP associates with the protein tyrosine phosphatase SHP-2 in response to growth factors such as IL-3 and erythropoietin (Liu et al. 1997b; Sattler et al. 1997). Because the activity of SHP-2 is postulated to contribute to Ras-MAP kinase activation, association of SHIP with SHP-2 could modulate activity of the Ras pathway. In addition, SHIP may compete with Grb2 for Shc, thereby regulating the levels of Shc-Grb2 association within the cell (Liu et al. 1994; Tridandapani et al. 1997). In either case, absence of SHIP could theoretically lead to enhanced Ras activity. Although we have not yet examined the phosphorylation of Shc or activation of the Ras pathway in cytokine-stimulated bone marrow progenitors, studies with IgE-stimulated SHIP-1- mast cells suggest that Shc phosphorylation is markedly reduced compared to IgE-stimulated $\mathrm{SHIP}^{++}$mast cells (M. Huber, C.D. Helgason, J.E. Damen, L. Liu, R.K. Humphries, and G. Krystal, in 
prep.). Experiments are now in progress to examine these biochemical pathways in more detail.

A second possible mechanism underlying the enhanced proliferative potential of SHIP ${ }^{-1-}$ granulocytemacrophage progenitors resides in the phosphatase activity of SHIP. The PI-3-K pathway plays an important role in signaling through cytokine receptors. For example, $\mathrm{PIP}_{3}$ is capable of stimulating members of the protein kinase C family (Toker et al. 1994), as well as modulating the activity of the Akt/PKB kinase ( $M$ arte and Downward 1997). In the absence of SHIP, which metabolizes this $\mathrm{PI}-3-\mathrm{K}$ product, uncontrolled activation of these pathways could result in enhanced cell survival and proliferation.

In conclusion, we have provided evidence that supports the hypothesis that SHIP is an important negative regulator of cytokine signaling in cells of the hemopoietic system. SHIP ${ }^{-1-}$ mice provide a powerful model in which to further explore SHIP function in hemopoietic stem and progenitor cell compartments, as well as in mature cells. In addition, studies with cells from these mice should further our understanding of the molecular mechanisms by which signaling thresholds are established in both mature cells and progenitors.

\section{Materials and methods}

\section{SHIP gene targeting}

A genomic DN A library derived from the 129 mouse strain was screened with a 600-bp fragment derived from the $5^{\prime}$ end of the SHIP cDNA. Positive clones were analyzed by restriction mapping and sequence analysis. The targeting vector was engi neered to contain a 254-bp A pal-BamHI deletion, thus effectively removing the transcriptional start site and most of the first exon. A Tk-neo cassette derived from pMC1TkN eoPolyA was subcloned into the deletion site in the opposite transcriptional orientation. The targeting vector contains $1.8 \mathrm{~kb}$ of SHIP homologous 5' DNA and $6.0 \mathrm{~kb}$ of $3^{\prime}$ SHIP genomic DNA. A second targeting vector was constructed to include the HSV-TK gene from pMC1-Tk at the $3^{\prime}$ end of the targeting sequence.

Each linearized targeting construct was electroporated into the R1 ES cell line and colonies were isolated following selection in either $\mathrm{G} 418$ al one or $\mathrm{G} 418$ plus gancyclovir. Genomic DNA was isolated from pools of 6-8 clones and analyzed by PCR analysis using Elongase (Life Technologies) to generate a 2662-bp amplicon derived from an internal Neo primer (5'CAAGATGGATTGCACGCAGG) and a 5' SHIP primer (G3: 5'-CCAGAAGTGTCTCTATCATGATAGT). Positive colonies were expanded and purified genomic DNA was digested with Kpnl and analyzed by Southern bl ot analysis using a 2-kb KpnlHindlII genomic probe. By Southern analysis, the nontargeted SHIP allele and the positively targeted allele were visualized as 4.6- and 5.8-kb bands, respectively. One clone out of 300 was positive using the double-selection protocol, whereas 7 positive clones were obtained with the single-selection vector. Similar blots were also probed with a $\mathrm{Neo}^{r}$ fragment to confirm single integrations (results not shown).

Germ-line transmission chimeras of cl one 4.8B (double-selection vector) and clone 5.1 (single-selection vector) were generated by injection of C57BL/6J blastocysts, followed by breeding onto a C57BL/6J background. Genotype analysis was routinely done using Southern blot analysis and the probe described above. Animals were housed in microisolator units and provided with sterilized food and water. Routine testing for viral pathogens and mycoplasma was carried out on both animal colonies in which the two independent lines were maintained.

Homozygous deletion SHIP ES cells were generated by gene conversion in increasing concentrations of G418 using previously described techniques (M ortensen et al. 1992). Southern blot analysis of genomic DNA confirmed the absence of the SHIP allele. Karyotype analysis was carried out on all clones used both in vitro and in vivo in this study.

\section{Western blot analysis}

Equivalent numbers of nucleated cells, derived from hemopoietic suspension cultures of day 10 embryoid bodies (differentiated as described previously; Helgason et al. 1996) generated with SHIP wild-type, heterozygous, and null R1 ES cells, were washed once in phosphate-buffered saline, solubilized with $1.0 \%$ Triton-X 100 at $4^{\circ} \mathrm{C}$, and subjected to Western blot analysis as described previously (Damen et al. 1993). Bone marrow cells from all three genotypes of mice were treated in a similar manner. The SHIP antibodies used for Western blot analysis were generated against the $\mathrm{SH} 2$ domain and the region spanning the two NPxY motifs using GST fusion proteins as described previously (Liu et al. 1997a).

\section{Preparation of sections and slides}

Selected organs were fixed in a buffered $4 \%$ paraformal dehyde solution, dehydrated in ethanol, and embedded in paraffin for sectioning. Sections were prepared and $H \& E$ stained at the Academic Pathology Laboratory, University of British Columbia, Vancouver using standard protocols. Cytospin preparations of bone marrow and spleen, as well as peripheral blood smears, were routinely stained with a modified Wright-Geimsa stain.

\section{Assays to detect clonogenic progenitors}

$\mathrm{Nucleated}$ cell counts were performed on bone marrow aspirates or cell suspensions of spleen, prepared using a nylon mesh screen. A ppropriate cell numbers were plated in a $1.1 \mathrm{ml}$ volume per Petri dish in standard conditions to detect the various clonogenic progenitors. All cell culture was carried out in a humidified incubator at $37^{\circ} \mathrm{C}$ with $5 \% \mathrm{CO}_{2}$. Bone marrow pre-B progenitors were detected by culture in methylcellulose media containing $10 \mathrm{ng} / \mathrm{ml}$ IL 7 for 5 to 7 days [StemCell Technologies Inc. (STI), Vancouver; Methocult M 3630]. Methocult M 3230 (STI) was supplemented with $50 \mathrm{ng} / \mathrm{ml}$ Steel factor (supplied as a supernatant from Cos cells engineered to express the protein) and $3 \mathrm{U} / \mathrm{ml}$ rhEpo for detection of day $2 \mathrm{CFU}-\mathrm{E}$ and day $3 \mathrm{BFU}-\mathrm{E}$. Methocult M 3434 (STI) containing $10 \mathrm{ng} / \mathrm{ml} \mathrm{rmlL}-3,10 \mathrm{ng} / \mathrm{ml}$ $\mathrm{rhlL}-6,50 \mathrm{ng} / \mathrm{ml} \mathrm{rmSF}$, and $3 \mathrm{U} / \mathrm{ml}$ rhEpo was used for the detection of myeloid (CFC), late erythroid, and multipotential progenitors in bone marrow and spleen cell preparations. All colonies were scored microscopically using standard criteria.

Bone marrow cells derived from mice of all three genotypes were cultured in Methocult M 3234 (STI) in the indicated concentrations of IL-3, rmGM-CSF (Peprotech), SF (supplied as a Cos supernatant), or rhM-CSF (Genetics Institute, Cambridge, $\mathrm{MA}$ ) for growth factor response curves. Colonies containing 20 or more cells were scored. In all cases duplicate determinations were performed on each sample. Statistical significance compared with the $H+$ populations was determined using the Student's t-test. 


\section{Flow cytometry}

Bone marrow, spleen, thymus, or lymph node cells at a density of $5-10 \times 10^{6}$ cells $/ \mathrm{ml}$ were incubated on ice for $30 \mathrm{~min}$ with 3 $\mu \mathrm{g} / \mathrm{ml} 2.4 \mathrm{G} 2$ (murine anti-lgG Fc receptor antibody) followed by incubation on ice for $40 \mathrm{~min}$ with the various FITC-labeled or phycoerythrine-conjugated antibodies. Cells were washed twice in Hank's balanced salt solution containing $2 \%$ fetal bovine serum at $4^{\circ} \mathrm{C}$ and propidium iodide (Sigma Chemicals, St. Louis, $\mathrm{MI}$ ) at a concentration of $1 \mathrm{ug} / \mathrm{ml}$ was included in the final wash. Cells were analyzed on a FACStar ${ }^{+}$or FACSort (BectonDickinson, San Jose, CA).

The monoclonal antibodies used for analysis included: E13161.7 (anti-Sca-1), RB6-8C5 (anti-Gr-1; granulocytes), M 1/70 (anti-M ac-1; macrophages), Ter119 (anti-erythroid lineage) (the sources of these antibodies have been described elsewhere; Rebel et al. 1996). Antibodies against CD4, CD8, B220, and CD1lb were purchased from Pharmingen (Mississauga, Ontario, Canada).

\section{Acknowledgments}

The authors thank James Ihle for hel pful discussions regarding the targeting strategy. In addition, the authors wish to thank Gayle Thornbury and Giovanna Cameron for expert technical assistance on the FACStar ${ }^{+}$, Gloria Shaw for karyotype analysis of the ES clones, Malin Parmar for assistance with PCR and Southern blot analysis, and Julie Chow for preparation and staining of the lung sections, as well as Rosemary Hood, Christian Kalberer, Ling Liu, and Cindy Miller for helpful discussions. This work was supported by the $\mathrm{N}$ ational Cancer Institute of Canada (with funds from the Canadian Cancer Society and the Terry Fox Run) and the Medical Research Council of Canada.

The publication costs of this article were defrayed in part by payment of page charges. This article must therefore be hereby marked "advertisement" in accordance with 18 USC section 1734 solely to indicate this fact.

\section{References}

Cutler, R.L., L. Liu, J.E. Damen, and G. Krystal. 1993. Multiple cytokines induce the tyrosine phosphorylation of Shc and its association with Grb2 in hemopoietic cells. J. Biol. Chem. 268: 21463-21465.

Damen, J.E., L. Liu, R.L. Cutler, and G. Krystal. 1993. Erythropoietin stimulates the tyrosine phosphorylation of Shc and its association with Grb2 and a 145-Kd tyrosine phosphorylated protein. Blood 82: 2296-2303.

Damen, J.E., L. Liu, P. Rosten, R.K. Humphries, A.B. Jefferson, P.W. Majerus, and G. Krystal. 1996. The 145-kDa protein induced to associate with Shc by multiple cytokines is an inositol tetraphosphate and phosphatidylinositol 3,4,5-trisphosphate 5-phosphatase. Proc. Natl. Acad. Sci. 93: 16891693.

Helgason, C.D., G. Sauvageau, H.J. Lawrence, C. Largman, and R.K. Humphries. 1996. Overexpression of HOXB4 enhances the hematopoietic potential of embryonic stem cells differentiated in vitro. Blood 87: 2740-2749.

Jiao, H., W. Yang, K. Berrada, M. Tabrizi, L. Shultz, and T. Yi. 1997. Macrophages from motheaten and viable motheaten mutant mice show increased proliferative responses to GM CSF: Detection of potential HCP substrates in GM-CSF signal transduction. Exp. Hematol. 25: 592-600.

Johnson, G.R., T.J. Gonda, D. M etcalf, I.K. Harihan, and S. Cory.
1989. A lethal myeloproliferative syndrome in mice transplanted with bone marrow cells infected with a retrovirus expressing granulocyte-macrophage colony stimulating factor. EMBO J. 8: 441-448.

Kapeller, R. and L.C. Cantley. 1994. Phosphatidylinositol 3-kinase. Bioessays 16: 565-576.

Kavanaugh, W.M., D.A. Pot, S.M. Chin, M. Deuterreinhard, A.B. Jefferson, F.A. N orris, F.R. M asiarz, L.S. Cousens, P.W. Majerus, and L.T. Williams. 1996. Multiple forms of an inositol polyphosphate 5-phosphatase form signal ing complexes with SHC and GRB2. Curr. Biol. 6: 438-445.

Lioubin, M.N., G.M. Myles, K. Carlberg, D. Botwell, and L.R. Rohrschneider. 1994. SHC, GRB2, SOS1 and a 150-kilodalton tyrosine-phosphorylated protein form complexes with Fms in hematopoietic cells. Mol. Cell. Biol. 14: 5682-5691.

Lioubin, M.N., P.A. Algate, S. Tsai, K. Carlberg, R. Aebersold, and L.R. Rohrschneider. 1996. p150 ${ }^{\text {SHIP }}$, a signal transduction molecule with inositol polyphosphate-5-phosphatase activity. Genes \& Dev. 10: 1084-1095.

Liu, L., J.E. Damen, R.L. Cutler, and G. Krystal. 1994. Multiple cytokines stimulate the binding of a common 145-kilodal ton protein to Shc at the Grb2 recognition site of Shc. Mol. Cell. Biol. 14: 6926-6935.

Liu, L., J.E. Damen, M.R. Hughes, I. Babic, F.R. Jirik, and G. Krystal. 1997a. The Src homology 2 (SH2) domain of SH2containing inositol phosphatase (SHIP) is essential for tyrosine phosphorylation of SHIP, its association with Shc, and its induction of apoptosis. J. Biol. Chem. 272: 8983-8988.

Liu, L., J.E. Damen, M.D. Ware, and G. Krystal. 1997b. Interleukin-3 induces the association of the inositol 5-phosphatase SHIP with SHP2. J. Biol. Chem. 272: 10998-11001.

Liu, L., J.E. Damen, M. Ware, M. Hughes, and G. Krystal. 1997c. SHIP, a new player in cytokine-induced signaling. Leukemia 11: $181-184$.

Marte, B.M. and J. Downward. 1997. PKB/Akt: Connecting phosphoinositide 3-kinase to cell survival and beyond. Trends Biol. Sci. 22: 355-358.

M ortensen, R.M., D.A. Conner, S. Chao, A.A.T. Geisterfer-Lowrance, and J.G. Seidman. 1992. Production of homozygous mutant ES cells with a single targeting construct. Mol. Cell. Biol. 12: 2391-2395.

N adler, M.J.S., B. Chen, J.S. Anderson, H.H. Wortis, and B.G. N eel. 1997. Protein-tyrosine phosphatase SHP-1 is dispensable for Fc $\gamma$ RIIB-mediated inhibition of B cell antigen receptor activation. J. Biol. Chem. 272: 20038-20043.

Ono, M., S. Bolland, P. Tempst, and J.V. Ravetch. 1996. Role of the inositol phosphatase SHIP in negative regulation of the immune system by the receptor FcyRIIB. Nature 383: 263266.

Ono, M., H. Okada, S. Bolland, S. Yanagi, T. Kurosaki, and J.V. Ravetch. 1997. Deletion of SHIP or SHP-1 reveals two distinct pathways for inhibitory signaling. Cell 90: 293-301.

Osborne, M.A., G. Zenner, M. Lubinus, X. Zhang, Z. Songyang, L.C. Cantley, P. Majerus, P. Burn, and J.P. Kochan. 1996. The inositol 5'-phosphatase SHIP binds to immunoreceptor signaling motifs and responds to high affinity IgE receptor aggregation. J. Biol. Chem. 271: 29271-29278.

Ravichandran, K.S., K.K. Lee, Z. Songyang, L.C. Cantley, P. Burn, and S.J. Burakoff. 1993. Interaction of shc with the zeta chain of the $T$ cell receptor upon $T$ cell activation. Science 262: 902-905.

Rebel, V.I., C.L. Miller, G.R. Thornbury, W.H. Dragowska, C.J. Eaves, and P.M. Lansdorp. 1996. A comparison of long-term repopulating hematopoietic cells in fetal liver and adult bone marrow from the mouse. Expt. Hematol. 24: 638-648.

Sattler, M., R. Sal gia, G. Shrikhande, S. Verma, J.-L. Choi, L.R. 


\section{Helgason et al.}

Rohrschneider, and J.D. Griffin. 1997. The phosphatidylinositol polyphosphate 5-phosphatase SHIP and the protein tyrosine phosphatase SHP-2 form a complex in hematopoietic cells which can be regulated by $\mathrm{BCR} / \mathrm{ABL}$ and growth factors. Oncogene 15: 2379-2384.

Saxton, T.M., I. Van Ostveen, D. Botwell, R. Aebersold, and M.R. Gold. 1994. B cell antigen receptor cross-linking induces tyrosine phosphorylation of the p21ras oncoprotein activators SHC and SOSI as well as assembly of complexes containing SHC, GRB-2, mSOS1, and a 145-kD tyrosinephosphorylated protein. J. Immunol. 153: 623-636.

Scharenberg, A.M. and J.-P. Kinet. 1996. The emerging field of receptor-mediated inhibitory signaling: SHP or SHIP? Cell 87: 961-964.

Shultz, L.D., T.V. Rajan, and D.L. Greiner. 1997. Severe defects in immunity and hematopoiesis caused by SHP-1 proteintyrosine-phosphatase deficiency. Trends Biotechnol. 15: 302-307.

Tazi, A., F. Bouchonnet, M. Grandsaigne, L. Boumsell, A.J. Hance, and P. Soler. 1993. Evidence that granulocyte macrophage-col ony-stimulating factor regulated the distribution and differentiated state of dendritic cells/Langerhans cell $\mathrm{s}$ in human lung and lung cancers. J. Clin. Invest. 91: 566-576.

Toker, A.M., M. Meyer, K.K. Reddy, J.R. Falck, R. Aneja, S. Aneja, A. Parra, D.J. Burns, L.M. Ballas, and L.C. Cantley. 1994. Activation of protein kinase $C$ family members by the novel polyphosphoinositides Ptdlns-3,4- $P_{2}$ and Ptdlns-3,4,5$P_{3}$. J. Biol. Chem. 269: 32358-32367.

Tridandapani, S., T. Kelley, D. Cooney, M. Pradhan, and K.M. Coggeshall. 1997. Negative signaling in B cells: SHIP Grbs Shc. Immunol. Today 18: 424-427.

Tsui, F.W.L. and H.W. Tsui. 1994. M olecular basis of the motheaten phenotype. Immunol. Rev. 138: 185-206.

Yi, T.L., J.L. Cleveland, and J.N. Ihle. 1992. Protein tyrosine phosphatase containing $\mathrm{SH} 2$ domains: Characterization, preferential expression in hematopoietic cells, and localization to human chromosome 12p12-p13. Mol. Cell. Biol. 12: 836-846. 


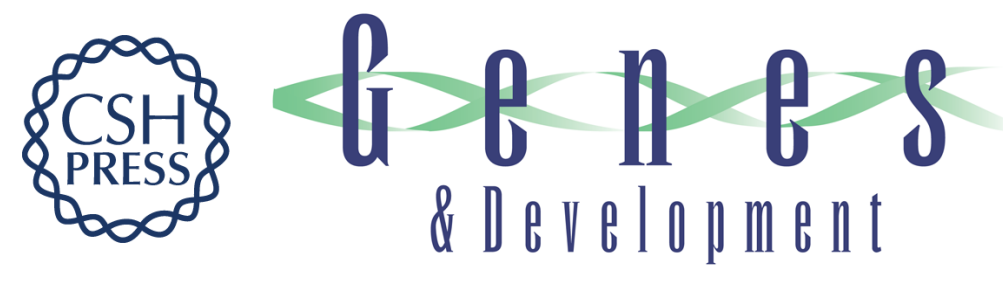

\section{Targeted disruption of SHIP leads to hemopoietic perturbations, lung pathology, and a shortened life span}

Cheryl D. Helgason, Jacqueline E. Damen, Patty Rosten, et al.

Genes Dev. 1998, 12:

Access the most recent version at doi:10.1101/gad.12.11.1610

References

This article cites 29 articles, 16 of which can be accessed free at: http://genesdev.cshlp.org/content/12/11/1610.full.html\#ref-list-1

License

Email Alerting

Receive free email alerts when new articles cite this article - sign up in the box at the top Service right corner of the article or click here.

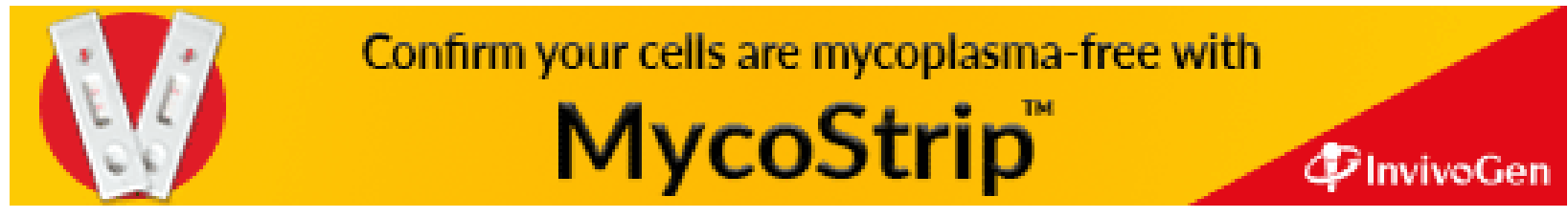

